\title{
THE EFFECT OF VISITORS IN A TOURISTIC CAVE AND THE RESULTING CONSTRAINTS ON NATURAL THERMAL CONDITIONS FOR PALAEOCLIMATE STUDIES (EAGLE CAVE, CENTRAL SPAIN)
}

\section{VPLIV TURISTIČNEGA OBISKA NA JAMSKO TEMPERATURO Z VIDIKA PALEOKLIMATSKEGA PREUČEVANJA NA PRIMERU ORLOVE JAME (CUEVAS DEL ÁGUILA) V ŠPANIJI}

\author{
David DOMÍNGUEZ-VILLAR ${ }^{1,2}$, Ian J. FAIRCHILD², Rosa M. CARRASCO ${ }^{3}$, \\ Javier PEDRAZA ${ }^{4} \&$ Andy BAKER ${ }^{5}$
}

\begin{abstract}
UDC 551.44:504(460)

David Domínguez-Villar, Ian J. Fairchild, Rosa M. Carrasco, Javier Pedraza \& Andy Baker: The effect of visitors in a touristic cave and the resulting constraints on natural thermal conditions for palaeoclimate studies (Eagle Cave, central Spain) Temperature in Eagle Cave, central Spain, was measured over a year to determine the effect of tourists on the natural environment. The mean cave temperature was $15.6^{\circ} \mathrm{C}$ in 2009 , with a seasonal amplitude of $<0.4^{\circ} \mathrm{C}$. Access of tourists to the cavern produces thermal anomalies of $<0.15^{\circ} \mathrm{C}$, which are recovered overnight in most cases. During days with high visitor numbers, cumulative thermal anomalies may persist from one day to the next, causing an increase of cave temperature for longer periods. However, this anthropogenic effect disappears soon after the number of tourists reduces, lasting less than a week in most cases. Cumulative thermal anomalies are $<0.02^{\circ} \mathrm{C}$ during most of the year and $<0.1^{\circ} \mathrm{C}$ in periods with large number of visitors. The anthropogenic effect on cave temperature is non-persistent and has a small magnitude in comparison with natural oscillations. Thus, long-term absolute temperatures obtained from Eagle Cave are not affected by visitors. The input of thermal energy caused by tourists is absorbed as latent heat by the cave (causing evaporation), which prevents the increase of baseline temperatures in the environment. A condensation process occurs over cave walls and speleothems. This is the re-
\end{abstract}

Izvleček UDK 551.44:504(460)

David Domínguez-Villar, Ian J. Fairchild, Rosa M. Carrasco, Javier Pedraza \& Andy Baker: Vpliv turističnega obiska na jamsko temperaturo $z$ vidika paleoklimatskega preučevanja na primeru Orlove jame (Cuevas del Águila) v Španiji

$\mathrm{Z}$ namenom ovrednotiti vpliv turističnega obiska na jamsko mikroklimo, smo v letu 2009 merili temperaturo v Orlovi jami v osrednji Španiji. Povprečna temperatura zraka v jami je bila $15,6^{\circ} \mathrm{C}$ z letno amplitudo manjšo od $0,4^{\circ} \mathrm{C}$. Prisotnost turistov $\mathrm{v}$ jami povzroči temperaturne spremembe manjše od $0,15^{\circ} \mathrm{C}$. Izven glavne sezone se ta motnja preko noči izniči, $\mathrm{v}$ času visokega obiska pa temperaturni vpliv traja v naslednji dan, kar povzroči povišano temperature tekom daljšega obdobja, a le redko dlje kot teden dni. Letni kumulativni vpliv obiskovalcev na temperaturo $\mathrm{v}$ jam znaša manj kot $0.02^{\circ} \mathrm{C}, \mathrm{v}$ obdobju največjega obiska pa je manjši od $0,1^{\circ} \mathrm{C}$. Vpliv obiskovalcev je torej prehoden in majhen $\mathrm{v}$ primerjavi $\mathrm{z}$ naravnimi spremembami temperature. Del toplote, ki jo v jamo prinesejo obiskovalci, se preko izhlapevanje shrani v obliki latentne toplote. V času ohlajanja se del vodne pare kondenzira, a je kondenzirane vode premalo, da bi bili njeni korozijski učinki vidni. Jama je v dobrem toplotnem ravnovesju $\mathrm{z}$ zunanjo okolico in kot taka primerna za paleoklimatske študije, kljub temu, da je turistična.

\footnotetext{
${ }^{1}$ Departamento de Geología, Universidad de Alcalá, Ctra. A-II km 33.600, Alcalá de Henares, Madrid, Spain, email: d.domínguezvillar@bham.ac.uk

${ }^{2}$ School of Geography, Earth and Environmental Sciences, University of Birmingham, Edgbaston, B15 2TT, Birmingham, UK, email: i.j.fairchild@bham.ac.uk

${ }^{3}$ Departamento de Ingeniería Geológica y Minera, Universidad de Castilla-La Mancha, Av. Carlos III s/n, 45071, Toledo, Spain, email: rosa.carrasco@uclm.es

${ }^{4}$ Departamento de Geodinámica, Universidad Complutense de Madrid, C/ José García Novais 4, Ciudad Universitaria, 28040 , Madrid, Spain, email: javierp@ucm.es

${ }^{5}$ Connected Waters Initiative, Water Research Laboratory, University of New South Wales, 110 King St, Manly Vale, 2093, NSW, Australia; affiliated to the National Centre for Groundwater Research and Training, email: a.baker@unsw.edu.au
}

Received/Prejeto: 05.08.2010 
tion with cave walls once visitors leave. Although condensation is found in Eagle Cave, the magnitude of the process is not enough to cause any significant condensation corrosion that could damage speleothems as a result of the tourist visits. The cave is in thermal equilibrium with surface temperatures, and calibration studies will produce suitable results for palaeoclimate studies despite being a tourist cavern.

Keywords: tourists impact, cave temperature, pallaeoclimatic research.
Ključne besede: vpliv turističnega obiska, jamska temperatura, paleoklimatska proučevanja.

\section{INTRODUCTION}

During the past decade cave archives, especially those obtained from stalagmites, are being considered among the best-resolved and reliable palaeoclimate series, together with ice cores in the poles and ocean cores (e.g. Wang et al. 2001; Drysdale et al. 2007; Domínguez-Villar et al. 2009a). However, interpretation of speleothem time series can differ dramatically from cave to cave and even from stalagmite to stalagmite in the same system, since cave dynamics, and hence stalagmite records, depend on local conditions (Fairchild et al. 2006). Thus, complete monitoring studies of cave systems are recommended to better understand the processes taking place in order to improve stalagmite record interpretations (e.g. Spötl, et al. 2005; Banner et al. 2007).

Temperature is one of the basic parameters to define climate and consequently has been broadly surveyed in order to describe cave microclimate (Badino 1995). Temperature in shallow caves is frequently rather stable and its value is thought to be equivalent to the mean annual temperature above the surface of the cave (Wigley \& Brown 1976). This is roughly the case if temperature is measured far away from the entrance to prevent any thermal influence from the exterior and if the cavity is not thermo-regulated by dynamic ventilation, a water stream passing through the cave or geothermal fluxes. Many palaeoclimate studies used the cave thermal stability to infer changes in mean annual temperature in the exterior from cave temperatures based on oxygen isotope records, since oxygen-isotope fractionation is temperature-dependent (e.g. Dorale et al. 1992; Lauritzen
\& Lundberg 1999; Bar-Matthews et al. 2003). Although usually today it is agreed that such a straight-forward correlation of temperature and stalagmite oxygen isotopes is unlikely (but see Mangini et al. 2005), cave temperature is a critical variable that in most cases drives the cave ventilation (e.g. de Freitas \& Schmekal 2003), and consequently indirectly affects multitude of parameters recorded in stalagmites. Therefore, cave temperature is a key parameter for causing variability in stalagmite records.

Tourists entering caves provide additional heat to the cave system and increase cavern temperatures (Cigna 1993; Hoyos et al. 1998; Pulido-Bosch et al. 1997; Fernández-Cortés et al. 2006). So, monitoring a tourist cave for the mean temperature values and the natural thermal variability could record biased values because of the effect of visitors. In those cases, conclusions obtained in the monitoring campaign would not be applicable for understanding the natural processes that formed stalagmite records before the cave was open to tourists. In this paper we study a tourist cave located in central Spain: Eagle Cave. The aim of the study is to quantify the thermal effect of tourists versus the natural variability in cave temperature and evaluate if the main temperature trends and absolute values can accurately be associated to external temperatures without being biased by the anthropogenic effects of visitors. Detailed processes involved in thermal regulation of the cave system are described, and the associated effects of condensation corrosion are evaluated.

\section{REGIONAL SETTING AND CAVE ENVIRONMENT}

Eagle Cave is a tourist cavern in Ávila province, central Spain (Fig. 1). The cave is in an isolated hill at $427 \mathrm{~m}$ asl, surrounded on one flank by the Avellaneda Beck, which soon discharges in the Tietar River. The hill is densely forested with evergreen oaks and shrubs that develop over a thick soil ( $>0.5 \mathrm{~m}$ where rock does not crop out). The 
soil has a thin surficial organic horizon, whereas most of the profile consist of clays and silt with some sand-sized particles of carbonates, quartz, feldspar and oxides. The hill is composed of dolostones interbedded in a thick schist series from the Cambrian (Odriozola et al. 1980). Granite rocks of Carboniferous age intrude the dolomites producing a skarn (Martín Escorza 1971), with iron oxides as the main mineralization. Oxides provide different tones of red colours to some sectors of the cave bedrock, which provides a wide chromatic scale to the scene, an extra attraction for visitors.

The cave was discovered in 1963 and opened to the public in 1964. Two doors close to each other and located at the same altitude were constructed to access the cave. The dense wooden doors are closed at all times except for the short periods when the visitors enter or leave the cave, which is not so different from natural ventilation conditions prior to the cave's discovery. A narrow gallery descends some metres from the entrance and communicates with a main hall around which short passages develop. Some of those passages were old entrances to the cave, but they are filled with flowstones or other sediments. The bedrock over the cave is around $20 \mathrm{~m}$ thick, and the ceiling on the main hall is on average 5-10 m high. The cave is densely decorated with speleothems, and formations are not only related to drip or pool sites since moonmilk, popcorn, anthodite and crust speleothems are found in different sectors of the cave, suggest- ing that evaporative processes may occur (Hill \& Forti 1997). Relative humidity in the cave is $>94 \%$ based on spot measurements, since continuous monitoring was prevented due to condensation processes in probes. This implies that relative humidity is frequently saturated $(100 \%)$. Cave walls are commonly wet, and formation of droplets can be observed as a result of condensation. Some speleothems and cave walls, particularly in the entrance, are severely affected by condensation corrosion, a process that dissolves carbonates since condensed air moisture is subsaturated in dolomite, calcite and aragonite (e.g. Dublyansky \& Dublyansky 1998; Sánchez-Moral et al. 1999). However, condensation corrosion does not affect all speleothem formations, which provides a great diversity of textures in cave formations and together with the variety of speleothem types provides extra value as a tourist attraction.

The cave is visited by some tens of thousands of visitors every year. Although the cave is open to the public 365 days per year the visits mostly concentrate on the weekends and vacations. The number of visitors per day is higher at Easter and other extended weekend vacations, preferentially in spring and autumn, whereas during summer tourists do not concentrate on particular days. Visitors access the cave either during the morning and afternoon periods, whereas no one is allowed in for an interval of 90 minutes at lunch time.

\section{METHODS}

Temperature has been measured in three different locations inside the cave, and one logger was deployed outside the cave over the hill. The sites ET and Rino are in the main hall, whereas EC is located at the end of a small passage that communicates with the main hall (Fig. 1). Temperature was measured with thermistors, TinyTag Plus 2 loggers, which provide a resolution of $0.001^{\circ} \mathrm{C}$; calibration within the cave resulted in an accuracy better than $\pm 0.05^{\circ} \mathrm{C}$. The loggers were deployed directly over the cave floor since it represents similar conditions to speleothems; in contact with both cave floor and atmosphere. Temperature was measured during the whole of 2009, and readings were taken every 10 minutes.

Calculation of daily temperature anomalies was considered from the difference of the average temperature recorded in the period when tourists enter the cave and the average temperature values recorded the same day the hours prior to the opening of the cave to the public. This is defined in equation 1:

$$
\Delta \mathrm{T}_{d}=\left(\frac{\sum_{t e}^{t l} \mathrm{~T}}{\mathrm{n}_{l-e}}\right)-\left(\frac{\sum_{t 1}^{t 2} T}{n_{2-1}}\right),
$$

where $\Delta T_{d}$ is the daily thermal anomaly, $T$ is the recorded cave temperature, te is the time when visitors enter the cave and $t l$ when they leave, $t 1$ and $t 2$ represent a time interval of 150 minutes taken that morning before the tourist arrival, whereas $n_{l-e}$ and $n_{2-1}$ are the number of recorded readings in both time intervals. Small negative anomalies result from days with no or small number of visitors, because instrument noise in the signal was equivalent or higher than the anomaly. Therefore, negative anomalies have been filtered.

The cumulative thermal anomaly caused by visitors represents the increment of temperature that persists from the previous day as a result of the tourists. To calculate it, only the average of the previous hours up to the opening of the cave was considered each day. A 


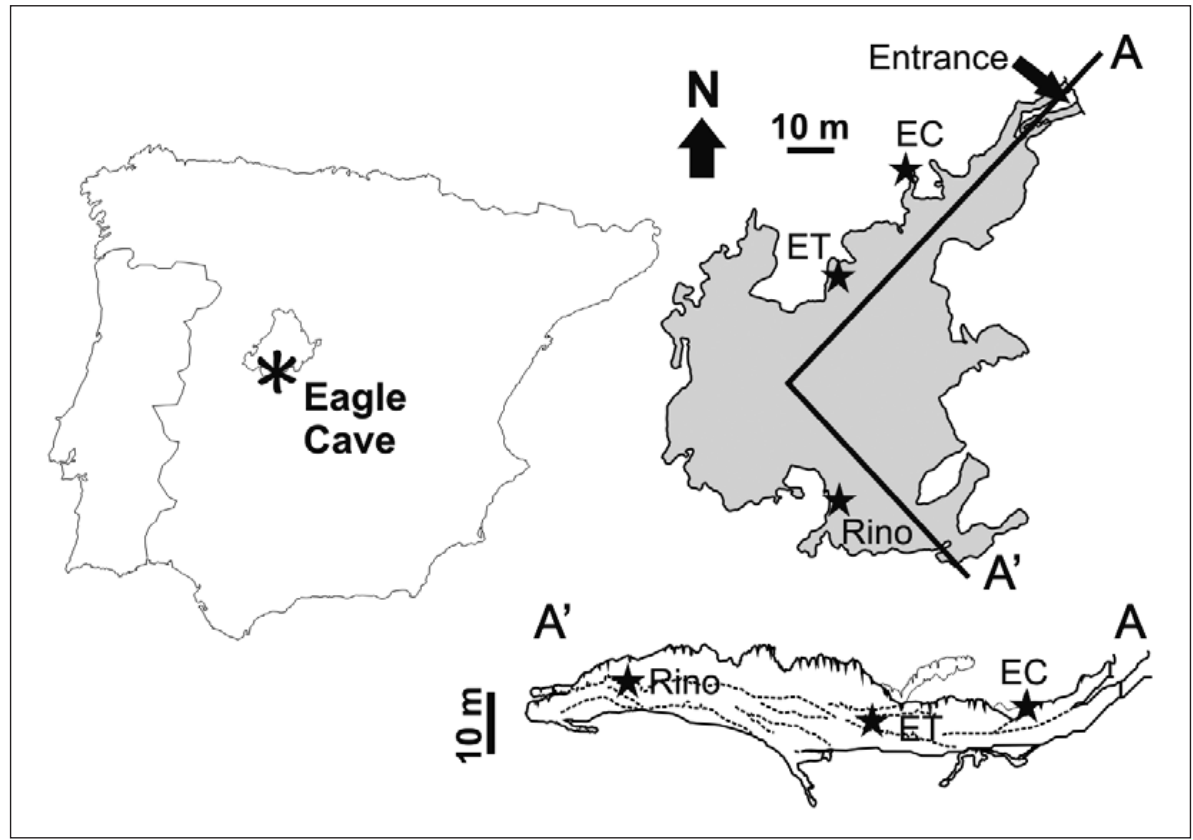

Fig. 1: Situation of Eagle Cave in Ávila province (central Spain) and map of the cavern with the location where the three loggers where deployed (stars). Additionally, a cross section of the cave following the profile $A$-A' shows the altitude relationship among loggers.

weekly filter was applied to these data to split natural and anthropogenic signals, and the result of the cumulative anomaly due to visitors was based on the subtraction of the filtered data from the raw data series:

$$
\Delta T_{c}=\left(\frac{\sum_{t 1}^{t 2} T}{n_{2-1}}\right)-\left[\frac{\sum_{d 1}^{d 7}\left(\sum_{t 1}^{t 2} T / n_{2-1}\right)}{7}\right],
$$

where $\Delta T c$ is the cumulative thermal anomaly, whilst $d_{1}$ and $d_{7}$ represent a time interval corresponding to seven days.
The natural anomalies $\left(\Delta T_{n}\right.$ in equation 3$)$ were calculated from filtered data series once the thermal cumulative anomalies caused by visitors were subtracted. This was not necessary in one of the loggers (EC) where there was no impact of visitors and all variability was natural.

$$
\Delta T_{n}=\left[\frac{\sum_{d 1}^{d 7}\left(\sum_{11}^{t 2} T / n_{2-1}\right)}{7}\right]-\Delta T_{c} .
$$

\section{RESULTS}

The mean temperature of Eagle Cave during 2009 was $15.6^{\circ} \mathrm{C}$ with a range from 15.2 to $16.2^{\circ} \mathrm{C}$, depending on the location of the logger and the variability during the year. The temperature differences between the loggers Rino and ET, both in the main hall, are thought to be related to air stratification in the chamber, whereas the EC logger, located in a small gallery, followed an independent pattern suggesting air mass isolation during the monitoring period. A clear annual cycle was observed in all cave loggers and peak to peak amplitude of seasonality was from 0.25 to $0.4^{\circ} \mathrm{C}$ depending on the logger (Fig. 2). The cave reaches the maximum temperature during winter and minimum in summer, with some minor phase lags observed between the three loggers. Mean annual temperature outside the cave during 2009 was $15.1^{\circ} \mathrm{C}$, although the mean annual temperature recorded since 1990 based on meteorological stations in the region ranges from 15.3 to $15.6^{\circ} \mathrm{C}$, whereas the effect of altitude was not significant among considered stations. These regional temperatures are in good agreement with the current mean cave temperature.

The route of tourists is restricted to the entrance passage and the main hall. The loggers located in this hall (Rino and ET) record the influence of visitors with increases in temperatures. The logger situated in the small gallery near the entrance (EC) does not record any 


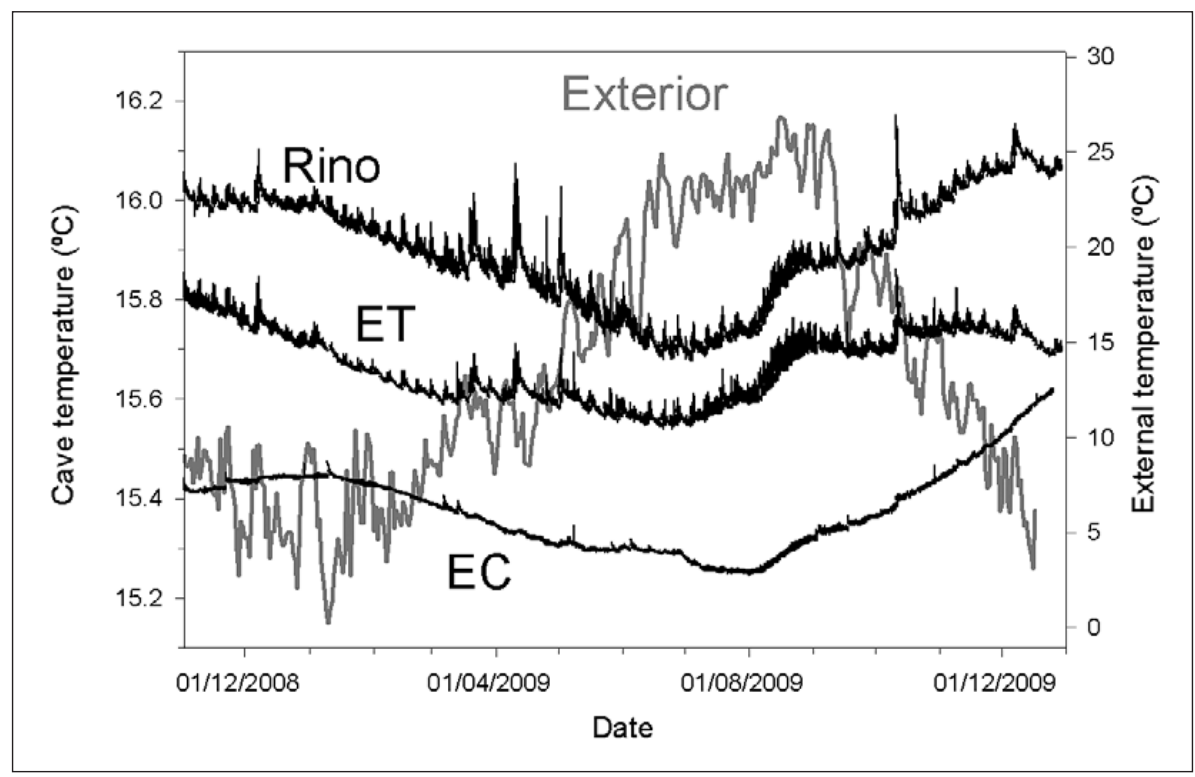

Fig. 2: Temperature record of the three loggers inside the cave: Rino, ET and EC. Temperature outside the cave is shown for comparison. Note the different scales for records from the cave and the external temperature.

effect of tourists (Fig. 2), even though the site is located less than $10 \mathrm{~m}$ away from the visitors track. The narrow opening that communicates this site with the main chamber isolates the end of the gallery where the logger is deployed. The loggers that detect the effect of visitors are sensitive enough to record morning and afternoon visit periods every day (Fig. 3). After the tourists have gone, temperature recovers overnight, reaching the baseline temperature recorded before the entrance of visitors. Thermal recovery is exponential, and most of the anomaly produced is mitigated within some hours. However, during weekends the thermal anomaly increases because of larger number of visitors (Fig. 4), and temperatures do not always recover overnight. In these cases a cumulative thermal anomaly is added to the baseline temperature for the next day (Fig. 3). Thus, the anthropogenic effect on cave temperature lasts longer, although as seen in Fig. 4 most weekends recover the thermal baseline within days.

Daily thermal anomalies in Eagle Cave during 2009 were less than $0.04^{\circ} \mathrm{C}$ much of the year, $<0.05^{\circ} \mathrm{C}$ in summer and $<0.15^{\circ} \mathrm{C}$ during short vacation periods when the rate of visits per day is higher (Fig. 5). Cumulative thermal anomalies recover in less than a week except in

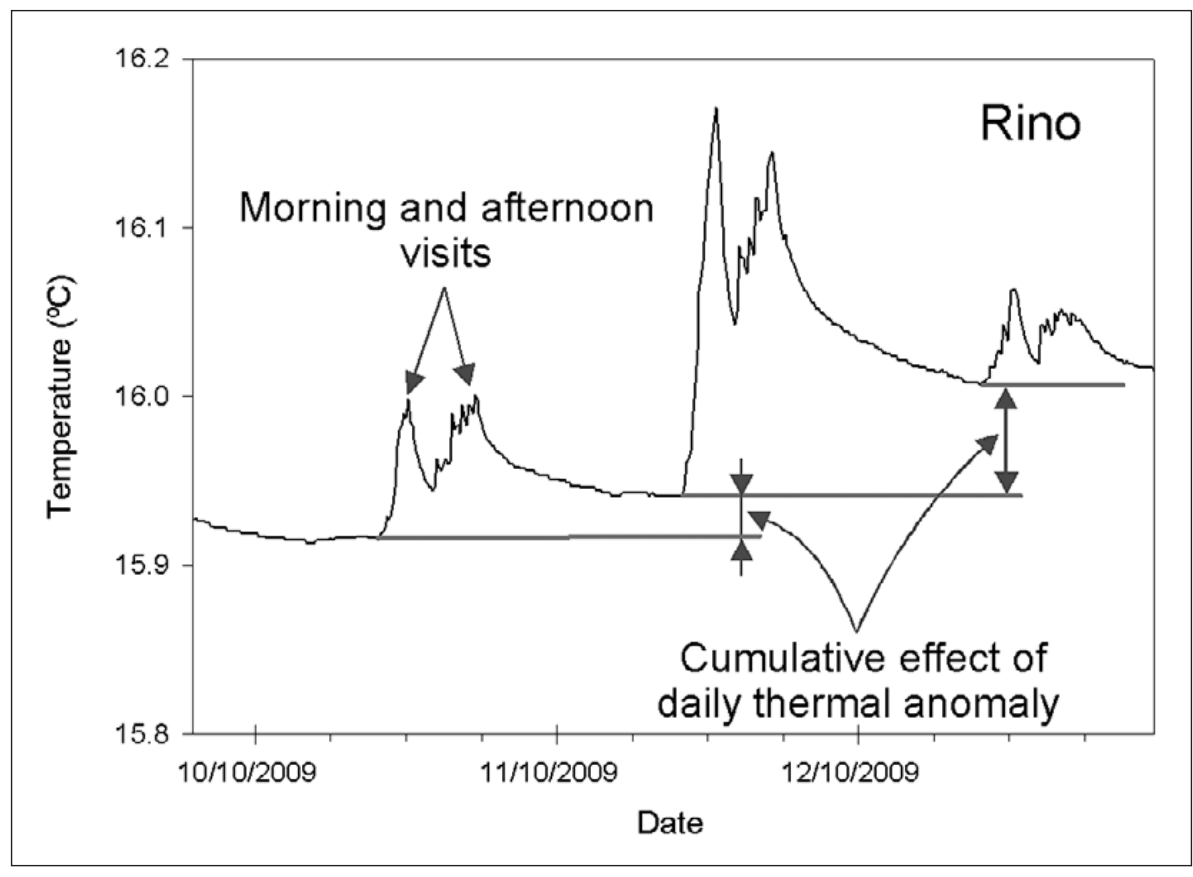

Fig. 3: Example of thermal anomalies during three days at the Rino site and the effect of thermal cumulative anomaly. 

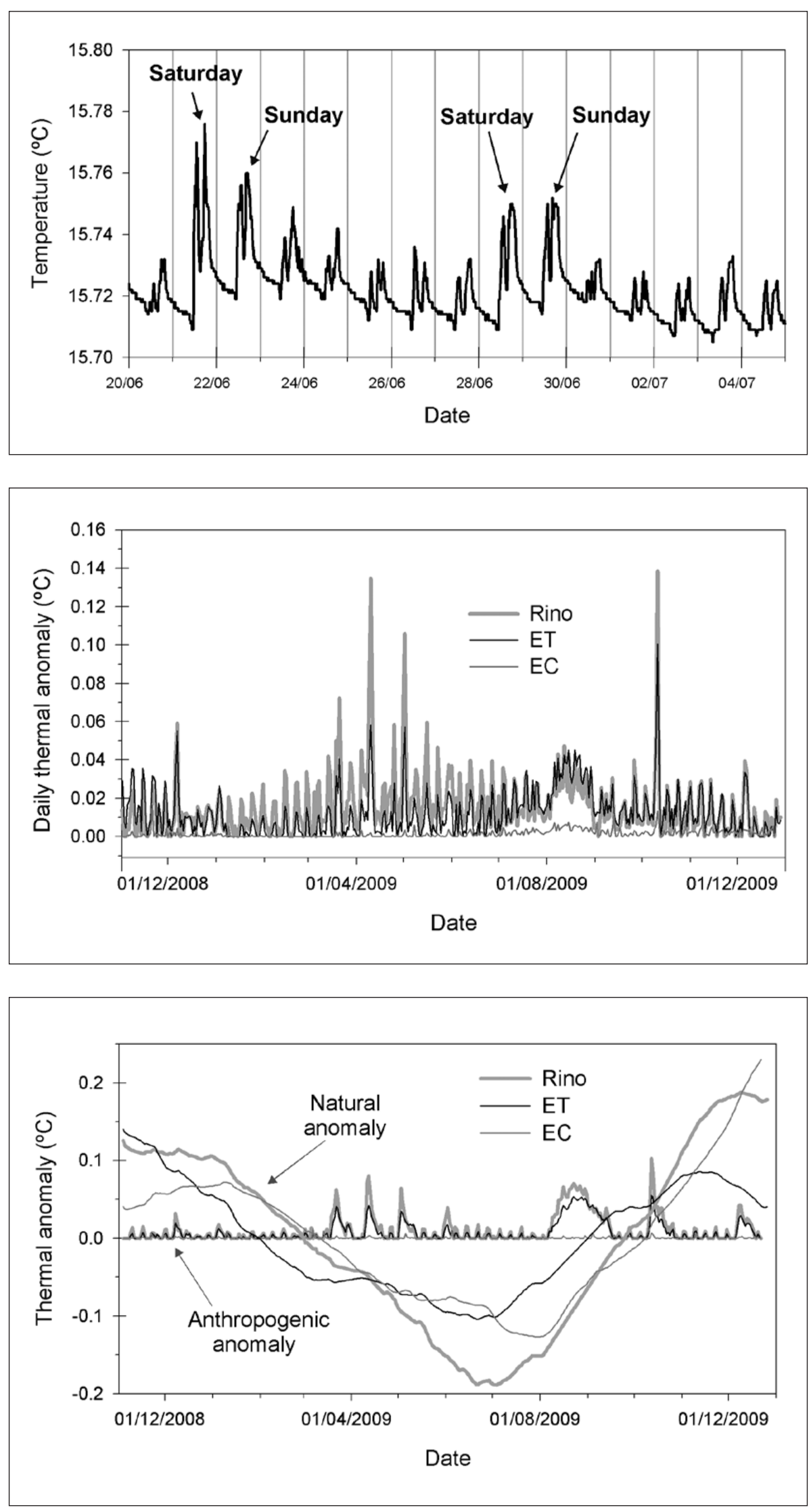

Fig. 4: Example of two weeks' temperature record at the ET site showing the increase of visitors during weekends and the recovery of cumulative temperature within the week.

Fig. 5: Daily thermal anomalies during the year.
Fig. 6: Cumulative thermal anomalies caused by visitors and natural thermal anomaly during the year. 
summer, when a large number of visitors are present not only on weekends, and in short vacation periods, because of large anomalies. These cumulative thermal anomalies were $<0.02^{\circ} \mathrm{C}$ during most of the year, with a duration frequently from 1 to 3 days, whereas maximum cumulative anomalies caused by visitors were $<0.1^{\circ} \mathrm{C}$ during vacations, with a recovery time lasting only some days after the number of visitors was reduced. The seasonality effect on cave temperature or natural anomaly is an order of magnitude higher during most of the year, and even during vacation periods the amplitude of natural oscillations is much more significant than the anthropogenic effects (Fig. 6). Additionally, natural variability is persistent whereas anthropogenic anomalies are not.

\section{DISCUSSION}

\section{CAUSES OF NATURAL AND ANTHROPOGENIC ANOMALIES}

The most outstanding feature recorded during the monitoring period is an annual cycle in temperature. Despite the fact that EC and ET loggers are not far away from the entrance, their records are not related to heat advection through the entrance passage. The narrow corridor that communicates between the cave and the exterior together with the high humidity (Wigley \& Brown 1971; de Freitas \& Littlejohn 1987) causes the relaxation length of this cave to be restricted to a few meters from the entrance (Domínguez-Villar et al.2009b). Advection of heat through fissures and significant heat input by drip waters have been also discarded as significant sources of thermal variability. The $10^{\circ} \mathrm{C}$ thermal range of drip waters during the year follows external temperatures and is anti-correlated with cave atmosphere temperature, confirming its insignificant influence on cave atmosphere temperature (Domínguez-Villar et al. 2009b). Thus, the temperature of the cave and its annual oscillation are related to heat conduction through the bedrock. The mechanism of temperature transport is as follows: the atmosphere heats the soil over the cave and soil heats the bedrock, which continues propagating the temperature signal downward by conduction. If the cave is shallow and no significant geothermal flux exists this would be the main heat source (e.g. Pollack \& Huang 2000). That is the case in Eagle Cave. The propagation of the thermal signal causes a mitigation of the amplitude of surface seasonality (Pollack et al. 2005). Seasonality is completely damped out beneath a certain depth, which in many carbonate rocks ranges from 25 to $50 \mathrm{~m}$ depending on the thermal diffusion coefficient. Transport of temperature by conduction takes some time to reach the caves. In comparison with soil temperature experiments, unless the caves are shallower than 10-15 metres depth, lag times longer than a year would be expected (e.g. Pollack et al. 2005; Smerdon et al. 2006; Mazarrón \& Cañas 2009).

External temperatures in the last two decades in the region $\left(15.3\right.$ to $\left.15.6^{\circ} \mathrm{C}\right)$ are in good agreement with mean annual cave temperature $\left(15.6^{\circ} \mathrm{C}\right)$, suggesting that Eagle Cave is nowadays in thermal equilibrium with atmospheric temperature. So, cave thermal anomalies related to natural variability are the result of transferring the atmospheric external temperature. As the bedrock overlying this site is $\sim 20 \mathrm{~m}$, external seasonality is substantially reduced $\left(<0.4^{\circ} \mathrm{C}\right)$ and the signal delay is expected to last longer than a year, where the minimum temperatures in summer do not represent a lag time of approximately half a year, but $n^{*} \pi$ years.

However, the visitors entering the cave have an obvious impact on cave temperature, even if this effect only represents some hundredths of a degree and its duration is ephemeral. The thermal auto-regulation mechanism that mitigates the anthropogenic effect is complex and involves three main heat sources and/or receivers: visitors, cave atmosphere and cave ceiling/walls (referred to only as cave walls during the rest of the paper). Additionally, as the relative humidity is very high, energy is not always transferred as sensible heat, but as latent heat whenever evaporation or condensation processes take place (Luetscher et al. 2008). Tourists introduce heat during their visits, which is transferred to the cave atmosphere as sensible heat, so its temperature increases. As the amount of water held in the atmosphere depends on temperature (Badino 1995; Massen et al. 1998; Fernández-Cortés et al. 2009), an increase in temperature causes the relative humidity to descend and hence evaporation processes are enhanced (Fig. 7). Evaporation is known to be very effective even with relative humidity $>98 \%$ (Buecher 1999). Water is abundant in the cave (pools, condensation over walls, drips), and evaporation commences immediately, causing visitors' heat to be partially transferred as latent heat. So, if cave walls do not dry due to excessive evaporation, their temperature would not change due to the effect of tourists because of the boundary layer of water film.

As more moisture is held in the air, the vapour pressure of the cave atmosphere increases. When visitors leave the cave they cease the energy input, and the 


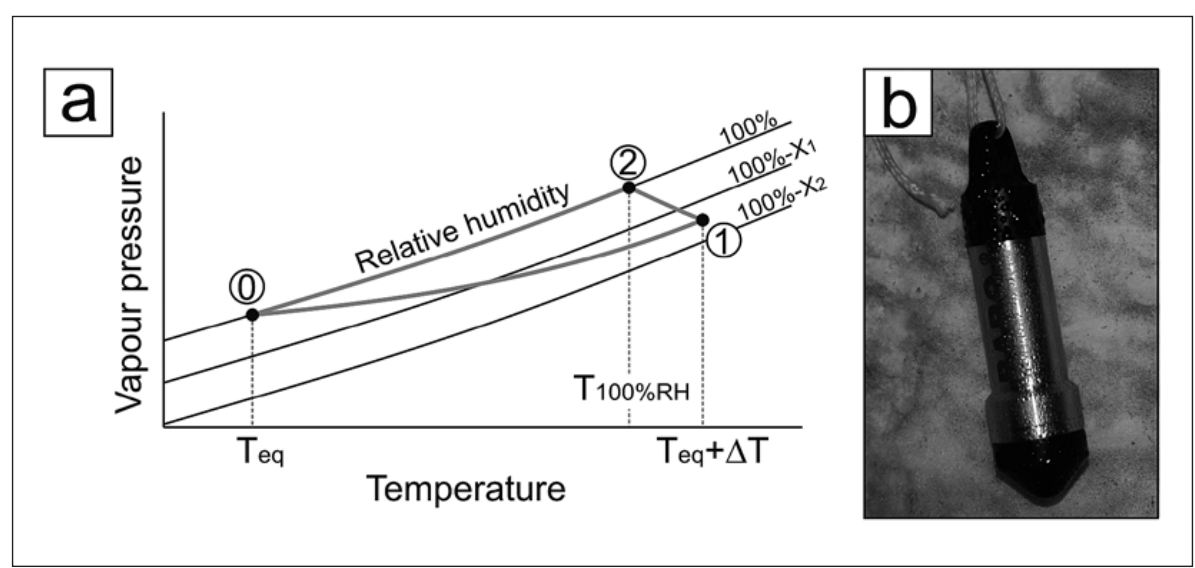

Fig. 7: a) Temperature versus vapour pressure in an idealized graph showing the evolution of cave atmosphere in relation to the visits. Stage 0 is assumed to have relative humidity $100 \%$ and air temperature equilibrated with cave walls. During the visit of tourists, air temperature increases towards stage 1 causing relative humidity to decrease, which results in evaporation and hence increases of vapour pressure. After stage 1 tourists leave and temperature begins to decrease in order to equilibrate with cave walls. Evaporation continues until saturation is reached in stage 2 and then condensation commences. The system is equilibrated when thermal equilibrium between cave atmosphere and walls is reached, and condensation remains over the cave walls. b) Example of condensed droplets from atmospheric moisture on a steel device deployed in the cave. Although condensation is more obvious over metals due to their specific heat properties, cave walls in Eagle Cave commonly present moist surfaces, and even droplets.

temperature of the atmosphere begins to equilibrate with the cave wall temperature. As the atmosphere is warmer, it gives heat to the walls. However, as the temperature descends, the capacity of moisture to be held in the atmosphere reduces, and saturation is easily reached. Under such conditions condensation of moisture takes place over the surface where the thermal equilibration is taking place. Thus, in Eagle Cave it is common to observe moistness and even droplets covering the walls (Fig. 7). During the condensation process, relative humidity in the atmosphere is maintained at $100 \%$ and vapour pressure progressively reduces while temperature goes down. As the condensation easily takes places in Eagle Cave, most of the energy liberated by tourists is not transferred to cave walls as sensible heat, but as latent heat since condensation occurs as an isothermal process. Thus, no significant temperature modification from natural variability is expected in cave walls, as is the case in wall temperatures measured in other cave systems (Bourges et al. 2006; Mazarrón \& Cañas 2009).

\section{CONDENSATION CORROSION IN EAGLE CAVE}

Several speleothems in Eagle cave have been affected by dissolution (Fig. 8), whose genesis is thought to be related to condensation corrosion. Alternative hypotheses to explain the observed dissolution of speleothems are $\mathrm{CO}_{2}$ inputs from deep fissures or the elevation of phreatic waters to re-flood cave galleries. There is no current hydrothermal activity in the region and no signs of such activity during the past million years, which makes improbable the occurrence of $\mathrm{CO}_{2}$-enriched air injections. The hypothesis of the cave being submerged is unlikely since the cave is situated in an outstanding hill in the landscape. Additionally, corroded speleothems grow over surfaces with clear evidence of ceiling collapse, and the scarce phreatic morphologies found predate the corrosion processes, which points towards dissolution processes occurring under vadose conditions. Therefore, dissolution caused by condensed cave atmosphere humidity is thought to be responsible for such corrosion.
Condensation of moist atmosphere occurs over cave walls and speleothems, which are mostly carbonates. The $\mathrm{CO}_{2}$ in cave atmospheres dissolves quickly in condensing solutions and the water becomes aggressive (Sánchez-Moral et al. 1999). In Eagle Cave $\mathrm{pCO}_{2}$ is $>2000 \mathrm{ppm}$ during the whole year due to the effective isolation of the cavity from the surface and the reduced ventilation rates, and condensates are expected to be slightly acidic. As the condensed solutions are undersaturated with respect to dolomite, calcite and aragonite they represent an aggressive solution that potentially may cause carbonate dissolution (Dublyansky \& Dublyansky 1998; Simms 2002). This dissolution process is known as condensation corrosion and is responsible for cave genesis in some cases (Audra et al. 2007), but causing damage in speleothems or cave walls too (Rozemarijn \& Ford 1998; Sánchez-Moral et al. 1999). Condensation corrosion is a process that has been very 
active in Eagle Cave, resulting in deep corrosion in speleothems (up to tens of centimetres of lost material). Speleothems subject to condensation corrosion are easily identified in Eagle Cave. They are mostly pristine white aragonite formations inside, but the outer surface is coated by reddish rust. Their external morphology has been modified, with blunt edges erasing several features from the original shape and typically they show internal structures, as laminations or clay-rich layers. However, those speleothems affected by deep condensation corrosion processes in Eagle Cave are et al. 2005). In consequence, the most likely cause of such severe condensation corrosion processes is a completely different ventilation system in the cave, probably as the result of larger entrances to the cave that caused strong daily temperature changes resulting in massive condensation in the cave. This condition was modified thousands of years ago, maybe caused by a collapse or sediment fills in the entrance/s, and the cave nowadays shows completely different conditions.

No visible damage caused by condensation corrosion is observed in currently growing speleothems, and dated speleothems that are inactive since thousands of years ago, when their drip site ceased, also do not show any corrosion features. Although some sectors of the cave walls show evidences of condensation corrosion, most likely they represent inherited features from when this process was active. However, sectors of the cave with block ceiling collapses containing speleothems from the "new generation" do not show any significant dissolution related to condensation corrosion. Thus, although condensation processes takes

clearly inactive, and a new generation of speleothems are growing with no evidence of condensation corrosion. Chronological studies in the cave based on U-Th dates on speleothems that were younger that those affected by condensation corrosion indicates that the deep condensation corrosion phase/s were older than $74.9 \pm 0.7 \mathrm{ka}$ (Domínguez-Villar unpublished data). Such deep speleothem corrosion probably is the result of intense thermal contrast over a long time. However, the highest dissolution rates are the result of thermal changes produced daily and not annually (Dreybrodt place in Eagle Cave and the solution should be undersaturated in carbonate minerals, the magnitude of the process is not enough to cause relevant condensation corrosion in the system. Therefore, the impact of visitors in the cave has no sign of any corrosion on speleothem formations. These observations in Eagle Cave are in agreement with other European caves where carbonate dissolution caused by visitors is less significant than other natural or anthropogenic mediated factors such as land use changes, cave ventilation, etc (Baker \& Genty, 1998).

\section{CONCLUSION}

Temperature in Eagle Cave was on average $15.6^{\circ} \mathrm{C}$ during 2009 , which is in agreement with long term atmospheric temperature in the region. Temperature from the surface is transferred to the cave by heat conduction through the bedrock, which causes a delay in the thermal signal measured in the cave and a mitigation of the seasonality.
Thus, minimum temperatures are found in summer, although the delay is thought to be longer than a year, and peak to peak amplitude recorded in the cave is $<0.4^{\circ} \mathrm{C}$. This seasonality is considered to be the natural thermal anomaly in the cave system. Visitors entering the cave produce daily increases in temperature, but commonly 
temperatures recover overnight. Periods with high rates of visitors during weekends or vacations prevent the thermal anomaly from being completely recovered in just one day, and there is a cumulative thermal anomaly. Daily thermal anomalies were generally $<0.04^{\circ} \mathrm{C}$ and in periods with a high rate of visitors $<0.15^{\circ} \mathrm{C}$, whilst cumulative anomalies were frequently $<0.02^{\circ} \mathrm{C}$, although values close to $0.1^{\circ} \mathrm{C}$ were occasionally measured.

Thermal anomalies of anthropogenic origin are in general one order of magnitude smaller than natural anomalies. Even during vacation periods, when large number of visitors causes the largest thermal and cumulative anomalies, the temperature perturbations are less important than the natural variability. Therefore, visitors in Eagle Cave produce small and not persistent thermal anomalies in comparison with natural variability. Anthropogenic thermal anomalies do not affect the longterm variability in the cave, and the recovery of recorded temperature due to visitors is the result of equilibration of atmosphere and cave wall temperatures. Cave water evaporation diminishes the thermal impact of visitors due to latent heat. Moisture excess is transformed in water via condensation during the cooling process once visitors leave the cave. Thus, the energy input of visitors is transformed in water, preventing the increase of the long term temperature in the cave due to tourists.
Atmospheric condensation produces a solution which is undersaturated in carbonate minerals. As a result a process known as condensation corrosion might take place. Many stalagmites are partially destroyed in Eagle Cave because of condensation corrosion. However, they represent a relict phase of speleothems dissolved when environmental conditions in the cave were dramatically different to nowadays. No perceptible condensation corrosion has been observed in recent speleothems. So, although condensation takes place in the cave as a result of tourists, the current magnitude of this process is not damaging the cave formations. Additionally, the speleothems affected by condensation corrosion represent an extra attraction for tourists since they increase the variety in colour, shape and texture of stalagmite formations.

This study has shown that despite of tens of thousands of visitors per year in Eagle Cave, its temperature can be related to external temperatures, whereas the tourist effect is almost negligible for long term trends and easily filtered out from the signal. So, cave records that could be related to temperatures can be used for past thermal reconstructions in the region, regardless of visitors' influence.

\section{ACKNOWLEDGEMENTS}

The research leading to these results has received funding from the European Community under a Marie Curie Intra-European Fellowship of the Seventh Framework Programme FP7/2007-2013 (grant agreement n 219891; PROCAVET project). Additional funds were provided from project CGL2008-03396/BTE (GLACIOSICE) funded by MICINN and PIIII09-0138-6113 (CRONOGREDOS) funded by JCCM. We would like to thank the cave managers whose collaboration facilitated the execution of this study.

\section{REFERENCES}

Audra, P., Hoblea, F., Bigot, J-Y., \& J-C. Nobecourt, 2007: The role of condensation corrosion in thermal speleogenesis: study of a hypogenic sulfidic cave in AixLes-Bains, France.- Acta Carsologica, 36, 185-194.

Badino, G, 1995: Fisica del clima sotterraneo.- Instituto Italiano di Speleologia, pp. 136, Bologna.
Baker, A., \& D. Genty, 1998: Environmental pressures on conserving cave speleothems: effects of changing surface land use and increased cave tourism.- Journal of Environmental Management, 53, 165-175.

Banner, J.L., Guilfoyle, A., James, E.W., Stern, L.A., \& M. Musgrove, 2007. Seasonal variations in modern speleothem calcite growth in central Texas, U.S.A.Journal of Sedimentary Research, 77, 615-622. 
Bar-Matthews, M., Ayalon, A., Gilmour, M., Mattews, A., \& C.J. Hawkesworth, 2003: Sea-land oxygen isotopic relationships from planktonic foraminifera and speleothems in the Eastern Mediterranean region and their application for paleorainfall during interglacial intervals.- Geochimica et Cosmochimica Acta, 67, 3181-3199.

Bourges, F., Genthon, P., Mangin, A., \& D. D’Hulst, 2006: Microclimates of L'Aven D'Orgnac and other French limestone caves (Chauve, Esparros, Marsoulas).- International Journal of Climatology, 26, 1651-1670.

Buecher, R.H., 1999: Microclimate study of Kartchner Caverns, Arizona.- Journal of Cave and Karst Studies, 61, 108-120.

Cigna, A.A., 1993: Environmental management of tourist caves.- Environmental Geology, 21, 173-180.

de Freitas, C.R., \& A. Schmekal, 2003: Condensation as a microclimate process: measurement, numerical simulation and prediction in the Glowworm Cave, New Zealand.- Internation Journal of Climatology, 23, 557-575.

de Freitas, C.R., \& R.N. Littlejohn, 1987: Cave climate: assessment of heat and moisture exchange.- Journal of Climatology, 7, 553-569.

Domínguez-Villar, D., Fairchild, I.J., Baker, A., Wang, X., Edwards, R.L., \& H. Cheng, 2009a: Oxygen precipitation anomaly in the North Atlantic region during the 8.2 ka event.- Geology, 37, 1095-1098.

Domínguez-Villar, D., Fairchild, I.J., Baker, A., Carrasco, R.M., Razola, L., \& J. Pedraza, 2009b: Factors affecting temperature variability in Eagle Cave (Spain): understanding the $2^{\circ} \mathrm{C}$ drop in temperature since 70's.- In: Gabrovšek, F., \& A. Mihevc (eds.) 17 International Karst School "classical karst": cave climate, $15-10^{\text {th }}$ June 2009, Postojna. IZRK ZRC SAZU, 56, Postojna.

Dorale, J.A., González, L.A., Reagan, M.K., Pickett, D.A., Murrell, M.T., \& R.G. Baker, 1992: A high-resolution record of Holocene climate change in speleothem calcite from Cold Water Cave, north-east Iowa.- Science, 258, 1626-1630.

Dreybrodt, W., Gabrovšek, F., \& M. Perne, 2005: Condensation corrosion: a theoretical approach.- Acta Carsologica, 34, 317-348.

Drysdale, R.N., Zanchetta, G., Hellstrom, J.C., Fallick, A.E., McDonald, J., \& I. Cartwright, 2007: Stalagmite evidence for the precise timing of North Atlantic cold events during the early last glacial.- Geology, 35, 77-80.

Dublyansky, V.N., \& Y.V. Dublyansky, 1998: The problem of condensation in karst studies.- Journal of Cave and Karst Studies, 60, 3-17.
Fairchild, I.J., Smith, C.L., Baler, A., Fuller, L., Spötl, C., Mattey, D., McDermott, \& E.I.M.F., 2006: Modification and preservation of environmental signals in speleothems.- Earth-Science Reviews, 75, 105-153.

Fernández-Cortés, A., Calaforra, J.M., Jiménez-Espinosa, R., \& F. Sánchez-Martos, 2006: Geostatistical spatiotemporal analysis of air temperature as an aid to delineating thermal stability zones in a potential show cave: Implications for environmental management.- Journal of Environmental Management, 81, 371-383.

Fernández-Cortés, A., Sánchez-Moral, S., Cuezva, S., Cañaveras, J.C., \& R. Abella, 2009: Annual and transient signatures of gas exchange and transport in the Castañar de Ibor cave (Spain).- International Journal of Speleology, 38, 153-162.

Hill, C., \& P. Forti, 1997: Cave minerals of the world.Second edition, National Speloelogical Society, Inc, pp. 463, Huntsville.

Hoyos, M., Soler, V., Cañaveras, J.C., Sánchez-Moral, S., \& E. Sanz-Rubio, 1998: Microclimatic characterization of a karstic cave: human impact on microenvironmental parameters of a prehistoric rock art cave (Candamo Cave, northen Spain).- Environmental Geology, 34, 231-242.

Lauritzen, S.-E., \& J. Lundberg, 1999: Calibration of the speleothem delta function: an absolute temperature record for the Holocene in northern Norway.- The Holocene, 9, 659-669.

Luetscher, M., Lismonde, B., \& P-Y. Jeannin, 2008: Heat exchanges in the heterothermic zone of a karst system: Monlesi cave, Swiss Jura Mountains.- Journal of Geophysical Research, 113, F02025.

Mangini, A., Spötl, C., \& P. Verdes, 2005: Reconstruction of temperature in the Central Alps during the past 2000 yr from a $\delta^{18} \mathrm{O}$ stalagmite record.- Earth and Planetary Science Letters, 235, 741-751.

Martín Escorza, C., 1971: Estudio mesotectónico en los materials metamórficos de los alrededores de Arenas de San Pedro (Prov. De Ávila-Toledo).- Boletín de la Real Sociedad Española de Historia Natural (Sección Geológica), 69, 303-327.

Massen, F., Dusar, M., Loy, W., \& N. Vandenberghe, 1998: Cave volume computed on the behaviour of a blowing well (Tournai basin, W. Belgium).- Terra Nova, 10, 131-135.

Mazarrón, F.R., \& I. Cañas, 2009: Seasonal analysis of the thermal behaviour of traditional underground wine cellars in Spain.- Renewable Energy, 34, 2484-2492.

Odriozola, J.M., Peón, A., Ugidos, J.M., Pedraza, J., \& P. Fernández, 1980: Arenas de San Pedro 578, 1:50:000.- MAGNA, Madrid. 
Pollack, H.N., \& S. Huang, 2000: Climate reconstruction from surface temperatures.- Annual Review of Earth and Planetary Science, 28, 339-365.

Pollack, H.N., Smerdon, J.E., \& P.E. van Keken, 2005: Variable seasonal coupling between air and ground temperatures: A simple representation in terms of subsurface thermal diffusivity.- Geophysical Research Letters, 32, L15405.

Pulido-Bosch, A., Martín-Rosales, W., López-Chicano, M., Rodríguez-Navarro, C.M., \& A. Vallejos, 1997: Human impact in tourist karstic cave (Aracena, Spain).- Environmental Geology, 31, 142-149.

Rozemarijn, F.A.T., \& D. Ford, 1998: Condensation corrosion in caves on Cayman Brac and Isla de Mona.Journal of Cave and Karst Studies, 60, 84-95.

Sánchez-Moral, S., Soler, V., Cañaveras, J.C., Sanz-Rubio, E., Van Grieken, R., \& K. Gysels, 1999: Inorganic deterioration affecting the Altamira Cave, N Spain: quantitative approach to wall-corrosion (solutional etching) process induced by visitors.- The Science of the Total Environment, 243, 67-84.

Simms, M.J., 2002: The origin of enigmatic, tubular, lakeshore karren: a mechanism for rapid dissolution of limestone in carbonate-saturated waters.- Physical Geography, 23, 1-20.
Smerdon, J.E., Pollack, H.N., Cermak, V., Enz, J.W., Kresl, M., Safanda, J., \& J.F. Wehmiller, 2006: Daily, seasonal, and annual relationships between air and subsurface temperatures.- Journal of Geophysical Research, 111, D07101.

Spötl, C., Fairchild, I.J., \& A.F. Tooth, 2005: Cave air on dripwater geochemistry, Obir Caves (Austria): Implications for speleothem deposition in dynamically ventilated caves.- Geochimica et Cosmochimica Acta, 69, 2451-2468.

Wang, Y.J., Cheng, H., Edwards, R.L., An, Z.S., Wu, J.Y., C.-C. Shen, \& J.A. Dorale, 2001: A high-resolution absolute-dated late Pleistocene monsoon record from Hulu Cave, China.- Science, 294, 2345-2348.

Wigley, T.M.L., \& M.C. Brown, 1971: Geophysical applications of heat and mass transfer in turbulent pipe flow.- Boundary-Layer Meteorology, 1, 300-320.

Wigley, T.M.L., \& M.C. Brown, 1976: The physics of caves.- In: Ford, T.D., \& C.H.D. Cullingford (eds.) The Science of Speleology. Academy Press, pp. 330358, London. 